\title{
Integration of cultural education in English teaching
}

\author{
Wu Yan \\ Sichuan Information Technology College, Guangyuan, Sichuan
}

\begin{abstract}
Language carries culture of a nation. Cultural differences can make people quickly enough to distinguish the characteristics of the nation based on linguistic features of a nation in complex modern society communication. Therefore, foreign language learning in the exotic culture of learning or an appropriate target interspersed cultural heritage can promote the exchanges better between the two cultures and also urge more students good learning good this language in the application of education and learning foreign culture.
\end{abstract}

Keywords- Culture and education, English teaching, New media teaching

\section{Introduction}

Language is an important carrier of culture, is a concrete manifestation of the inner one nation, the relationship between the two is very close. People communicate daily life and emotional life by means of language, which not only represents the history, customs, culture and other aspects of communication. Now English teaching enables students to learn the language of other ethnic groups in the classroom at the same time finds itself in the cultural characteristics of the communication skills to master, and jump out from the original cultural knowledge, in shows that the understanding of Chinese and western cultural exchange and at the same time can gain on own literature self-restraint.
2. The necessity of cultural education in English teaching implementation

\subsection{Cultural differences are two culture communication barriers}

The process of human civilization lies on the main cultural heritage of communication, so language learning has become the essence of our development in our life. However, on the issue of cultural differences, if the differences between the two can not be crossed, it will become a major obstacle to the development of both.

There are always different ethnic cultural differences, but there is also something in common between the two considering the pair. In considering between the two, according to the common cultural summarize, learn from each other through the national culture is an effective way to promote national cultural progress. So adding instilling understanding of national culture, in English teaching can better promote students to think in the history of Chinese and western cultural differences to further promote exchanges. During the studies students have to learn to understand the differences between the two cultures, and point to the fact, stand on the scientific point of comparative study of two kinds of culture, to understand the importance of interdependent development.

\subsection{Cultural education is the key to practical communication}

Language communication ability reflects a nation's ability to learn. After has the ability to learn, although this does not mean that the species 
will occupy the initiative, but on another level, the ultimate goal of this teaching is to cultivate students to obtain and inhomogeneity between communicative ability. More and more people have been able to understand the truth of this idea lies, communicative competence includes several aspects, most notably reflected in four aspects whether people have such capabilities were listening, speaking, reading and writing .

\section{Cultural content into English teaching}

In English teaching practice, the cultural difference is the interference to apply the main obstacle to learn English

\subsection{The differences of self-introduction}

First of all, in our textbooks "What 's your name?" are frequently appearing in the conversation. In western countries, people rarely ask during the conversation, this law will usually appear in court, is a question. And communication in western countries can be seen from the film, is similar with our language, "Your name, please" and Chinese "what is your name? "is the same.

And Chinese "what" to be translator directly translated as "what", has changed the tone of the language. If the actual use such words are likely to produce unnecessary misunderstanding.

\subsection{The differences of greeting}

In our daily greeting between Chinese will usually ask, "Did you eat?" If translated directly, it is such a sentence: "Have you had your dinner?" IF you say such things in western it shows that you are interested treat they eat, because the main fatal problem is that the weather and the obvious problems of health in their mind.

\subsection{Address differences}

In Western countries, their common appellation stranger is that for men with Sir, ladies and Madam. If we appellate Comrade when talking to people in these countries, they will feel strange just because we always use Chinese thinking to translate English. Cite a simple example, Chinese people are not familiar with the often address him uncle, uncle, brother, sister, etc., but in Western thinking these relatives appellation is not widely used. On the call for teachers and Chinese elders is a honorific title, but in Western thinking, they tend to think of it as a career.

\subsection{Differences in the form of thanks}

Generally speaking, among our family members rarely use thanks terminology used will feel very strange, even feel the distance between two people produce. However, in the case of English, thanks for the "Thank you" become a snake oil, even between parents and siblings, all ideological conflict does not occur. People in the West view of the world, no matter what you do to help others should say thank you, this is a basic respect for others.

\subsection{Praise differences}

In China, people often say, "No, not as good as you say." to express modesty, but westerners only say one sentence: "Thank you" in the face of other people's praise. There is a typical story to explain such a problem:

A pair of good friend, the western girl to come to China girl home, seen the girl for the first time to praise the girl dress was very good-looking, Chinese girl gave the dress to the western girl. After a while, the western girl came again, again praised Chinese girl's skirt beautiful, Chinese girl at the time of off friends and packaged dress for her once more. At the third time of western girl to came to China girl's home again, again praised the western girl. Chinese girl in a low voice said, "This is my last a skirt, do you want?". From this story we can clearly understand that cultural 
differences led to a large extent on the exchange between people produce ambiguity.

\section{Socio-cultural application to practice English Teaching}

Humanities and social and cultural knowledge into teaching English is a meaningful and influential practice, but it is also obvious difficulty. Since the Chinese teachers do not understanding Western culture very well, which they can not tell the difference between the two led to the intuitive explanation. The lack of cultural information also caused them to learn the process of English teaching can not really appreciate the cultural charm.

\subsection{The practice application of vocabulary}

Vocabulary learning is an important part of learning English. When English-language peer analysis based on word refers to the analysis of the problem, to demonstrate from different sense, to express psychological connotations of different cultures, thereby causing students to think of things to some extent, it can help students understand the differences in culture.

So peer teaching during the vocabulary, we need to convey to the students on the cultural differences between the two, to ensure that students learn by hear further learned from reading vocabulary inner meaning. Furthermore, vocabulary study, based on the specific expression cultural values, should stand in the perspective of the different social conduct tactful grammar learning, such as in Chinese and English and have a lot of the same kinds of words to express different meanings, its expression meaning just to avoid some ominous words at the same time, let people know what this means.

\subsection{The dictation synchronization}

During dialogue scenes, depending on the work and from pastime to set up a dialogue within the scene, is a response to foreign life, this scenario dialogue form of communication allows students to further cognitive of west culture. Through this type of conversation analysis, and comparison of existing means of communication, can better promote student awareness of the Anglo-American life.

\subsection{Read the text and introduce cultural education}

Culture learning in reading is the main source of access to information channels, this is also the student's strengths in our country. English courses in college, not usually open reading course, and the main problem with reading is focused on the students' self-study. In this kind of teaching, students should not only analyze the language materials and knowledge tendency of cultural understanding, understanding of different cultures can help to students' all-round development and understanding of the content of the meaning of the article.

\subsection{Introducing cultural learning writing}

Writing is a test of students in English proficiency to master the most comprehensive training. Students can study by writing ligatures regularity Reflections on words and grammar, language skills through a fixed analysis of cultural competence to practice, can better promote the students' grasp of knowledge. And exercise them through training on the subject sentence conceived from Western way of thinking in writing, on the content and discourse final confirmation of the overall logic of the idea

\section{Conclusion}

Integration of cultural education in English teaching, we can better facilitate the application awareness of such knowledge. Through this 
teaching philosophy, it allows students fundamental understanding and use of English and in the future development, develop their own strengths. Language talents during the construction of a new era in implementing cultural heritage education teaching, is a modern country in a new field of teaching English, should be popularized in all stages of teaching.

\section{Reference}

[1] Huang Zhi-qing, Let the culture education into English teaching, Journal of test questions and research: the new curriculum $B B S$, vol.18, pp.10-10, 2011.

[2] Sun Jun-lin and Zhou shan, Introduction to culture into English teaching in education , Journal of Hebei radio and television university, vol.03, pp.60-62, 2009.
[3] Li na, cultural education into English teaching high school course. Teaching research, vol.06:28, pp.59-60, 2012.

[4] Xu Xia, Analyses the cultural education in junior middle school English teaching, Journal of grand view weekly, vol.35, pp.142, 2011.

[5] Sun Ling. Talk about English teaching in cultural education, Journal of Inner Mongolia radio and TV university, vol.02, pp.100-101, 2006.

[6] He Yi. Integrated into the culture education in college English teaching analysis, Journal of Guangxi education (vocational and higher education edition), vol.12, pp.128-129, 2012.

[7] Li Dong-mei, Into the cultural education in junior middle school English teaching, Journal of exam, vol.84, pp.115-116, 2012. 